\title{
Krležina demaskiranja mentaliteta ili “i mjesečina može biti pogled na svijet”
}

\author{
SUZANA MARJANIĆ \\ Institut za etnologiju i folkloristiku, Zagreb
}

\begin{abstract}
U članku tematiziram Krležina demaskiranja mentaliteta, odnosno pogleda na svijet, i to preko figure faustovskoga Doktora iz romana Na rubu pameti (1938.), koji dakako kao autorov alter ego (jedan od njegovih alter ega) ne posjeduje pogled na svijet, jer za njega, ironijski, "i mjesečina može biti pogled na svijet". Time je uspostavljena negativnokvalitativna atribucija mentaliteta (pogleda na svijet koji plazi/e "kao zmijurine po prašumama”), za razliku od autonomnoga predočavanja i iskustva života. Odnosno, Krležinim određenjem iz 1971. godine: "Mentaliteti su ti koji razdvajaju ljude i narode, a to nam dokazuju svi građanski ratovi unutar jednog jedinstvenog jezičnog područja." U drugome dijelu rada kontrapunkt mentaliteta i autonomije promatram na dvama odabranim recentnim primjerima - jednom iz akcionističke/ alterglobalističke prakse, a drugom što se tiče državnoga ceremonijala - povodom ulaska RH u EU.
\end{abstract}

Ključne riječi: Miroslav Krleža, Na rubu pameti (1938.), mentaliteti, ulazak RH u EU

S ljudima zajedno smrdi, ali je toplo.

Miroslav Krleža, Na rubu pameti

Maji i Dunji ili Dunji i Maji

Dvije su istraživačice Instituta za etnologiju i folkloristiku u Zagrebu - Maja Bošković-Stulli i Dunja Rihtman-Auguštin - dakako svaka iz vlastitih pozicija, bile fascinirane Krležinim demaskiranjem mentaliteta, stoga je i ova tekstualna koncentracija svojevrsna posveta, rekao bi Krleža, spiritistička seansa, dakako u plemenitom, kolegijalnom smislu riječi. Maja BoškovićStulli u knjizi Priče iz moje davnine (2007.) navodi kako su na Krležin sukob na ljevici bili pripremljeni svi oni koji su čitali njegovu književnost. Dakle, ništa ih nije iznenadilo kada je 1938. godine objavljen autsajderski roman Na rubu pameti (Biblioteka nezavisnih pisaca, Zagreb, 1938.), roman koji je Ivo Kozarčanin aforistički odredio kao roman o ljudskoj gluposti (Kozarča- 
nin 1963: 218-221), ${ }^{1}$ te da su sve njihove simpatije, dakako, bile na strani samotnoga, protiv svih pobunjenoga, faustovskoga Doktora (Vučetić 1982: 140), pravnoga zastupnika u tvornici plehnatih škafova i noćnih lonaca, direktora Domaćinskog. Nadalje, Maja Bošković-Stulli dokumentira kako su mladi krležijanci u onome znamenitom zatvorskom razgovoru bili na strani Krleže za sviranje njegove vlastite melankolične pjesme, koja nije politička, ali je poštena, pa i za prednost čitanja Buddhe (kojega prema glasu razuma i strasti razumije Valent Žganec Stubičanec, zvan Vudriga) i svetoga Tome umjesto njemačkoga marksista Augusta Thalheimera, kojega Doktoru iz dogmatske vizure preporučuje inženjer Sinek. Riječ je o Doktorovoj osudi dogmatskih skidanja ljudskih glava zbog različitih pogleda na svijet, $^{2}$ i nasuprot svih tih pogleda na svijet - npr. slobodnozidarskoga (Arpad i Atila, Hugo-Hugo, Marko Antonije Javoršek i Oto-Oto), dogmatsko-monističkoga pogleda na svijet ortodoksnoga ljevičara inženjera Sineka, prema kojemu postoji samo jedna istina i ona se mora nametnuti makar i silom, a u ime te istine dopušteno je čak i ubiti, ${ }^{3}$ sindikalnosvjesnog, prvomajskog, tzv. modernog pogleda na svijet... Naime, deveto poglavlje "Lamentacija Valenta Žganca zvanog Vudriga", u kojemu Krleža ispisuje budistički traktat o "savršenom čovjeku”, koji je spoznao "da je užitak korijen svakoga zla, da biti i postojati znači rođenje, starost i smrt", sadrži Krležinu najopsežniju obradu Buddhina sižea na primjeru djela Manual of Buddhism (1853.) misionara Evangeličke metodističke crkve Roberta Spencea Hardyja (1803.-1868.).

Dakle, Maja Bošković-Stuli u navedenom se zapisu prisjeća Krleže kao izuzetno jake figure u okrilju zagrebačkoga revizionizma ${ }^{4}$ te otvara dvije teme: Krležin prvi politički roman Na rubu pameti (1938.) na liniji buddhiz-

\footnotetext{
${ }^{1}$ Ivan Goran Kovačić postavlja u paralelizam pojedine menipske konstative Erazma Rotterdamskog (Pohvala ludosti - Encomium Moriae) i prvo poglavlje “O ljudskoj gluposti” Krležina romana ispisanoga kao esejistički traktat o svemirskom poslanstvu vječnoponavljajuće i neuništive diluvijalne gluposti (Kovačić 1963: 223). U tome smislu navedeno prvo poglavlje možemo postaviti u interpretativni okvir s Krležinom pjesmom Tebi, o gluposti ljudska (1919., dio pjesničke cjeline pod nazivom Iz knjige Davni dani 1914-19.). O Erazmu Rotterdamskom kao Krležinu sugovorniku usp. natuknicu u Krležijani.

${ }^{2}$ Interpretativni antropolog Clifford Geertz razlikuje etos i pogled na svijet, ističući da se u novijim antropološkim raspravama moralni i estetski aspekti kulture, vrijednosni elementi, obično sažimaju terminom etos, dok se kognitivni, egzistencijalni aspekti označavaju terminom pogled na svijet (Geertz 1998I: 175). Krleža navedena dva termina značenjski spaja; za njega je kognitivni aspekt vrijednosna kategorija, te u tome smislu pogled na svijet, svjetonazor, u svjetovima romana Na rubu pameti (1938.), u kontekstu sukoba na ljevici, ima ideologijsku konotaciju.

${ }^{3}$ Inženjer Sinek, čije imenovanje upućuje na Staljinovu formulu pisca kao "inženjera ljudskih duša" i na postojanje političkoga "oca”, "baćuške" (Flaker 1999: 73-76), kao "nabožan čovjek” izlaže svoj "pogled na svijet" - dogmatski monizam koji pretendira na apsolutnost.

${ }^{4}$ Ivan Supek u knjizi Krivovjernik na ljevici (1980.) dokumentirao je da je Zagreb u doba Pečata bio svjetski centar otpora staljinizmu; zagrebački revizionizam figurirao je kao najheretičnija pojava u svjetskom komunizmu prije rata. Poslije likvidacije zagrebačkog revizionizma Milovan Đilas postaje čovjek broj 2 u KPJ, a Književne sveske prvo sistematsko izlaganje staljinizma u svim njegovim varijantama - od književnosti do politike (prema Lasić 1993, V: 120, Supek 1992: 54-66). Ivan Supek svjedoči da je u Kavani Corso bio Krležin "štamtiš” (Stammtisch) kao protuteža boljševizaciji s partijskoga vrha (Supek 1992: 53).
} 
ma i Schopenhauereova pesimizma, odnosno riječ je o optužbi tadašnjega socijalističko-realističkoga tabora Krležina romana za pad u "individualizam, skepticizam i solipsizam" zbog "kompromitirajućega” sedmoga poglavlja "I mjesečina može biti pogled na svijet", a pritom, dakako, i otvara temu sukoba na književnoj ljevici; odnosno zbog čega je Krležin Predgovor "Podravskim motivima" Krste Hegedušića (1933.) označio početak sukoba na ljevici a Dijalektički antibarbarus (Pečat, 1939: 8-9) njegovu kulminaciju. ${ }^{5}$

\begin{abstract}
dao. Rasplinuća obmana savršenu čovjeku znače rasplinuća obmana, on o njima ni na njih ne misli, on ne misli da su to "njegove obmane koje su se rasplinule", a zašto ne? Zato što je spoznao da su zadovoljstva i užici korijenje patnje i zla, da postojati i biti znači: rođenje, starost i smrt. I zato kažem ja da je savršen čovjek u sebi svaku žeđu za životom pogasio, da je u njemu žeđa za životom usahla, da je svaku životnu želju iz sebe iščupao i izlučio, da joj se uklonio i u sebi je nadvladao...

-To bi biti imalo, ak se pravzaprav zeme, ono, kagbirekli, kaj su pri pedeset i trečoj trumbentali kakti »ab-blazen«:
\end{abstract}

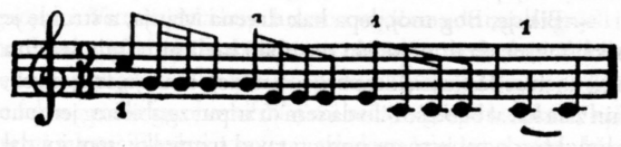

a tak i je, ak se prav zeme, kak veli ovaj Kinez: niškoristi se skup, aliti nirvana! Človeka zvlečeju z maternice kak pesa krvavog, a gda su ga prestali boleti zubi, javlaju se križa, a če ga nisu obesili, vumre kak pošten človek. Srab preboleti mora, na kolec se našpranjiti alpak na trn nabosti takaj mora (kajti prez toga mudrosti biti nemre), kača ga vpiknuti mora, sečka bu mu vre palec zdrobila, a onda kaj? Hižu si zazida, curu mladu v krevet povleče, a kaj ž nje postane? Cmizdrava baba,

179

Foto 1: Moćno performativan tekstualno-akustički kontrapunkt između autonomije (savršen čovjek u Doktorovu konceptu buddhističke nirvane) i heteronomije (akustički, vojni ab-blazen iz čijega iskustva proizlazi jedan takav savršen čovjek - Valentin Žganec) (Krleža 2004: 179), fragment. 0 tome da je za harkovsku liniju mjesečina književno bespredmetna usp. Krležin Predgovor "Podravskim motivima" Krste Hegedušića (1933.).

${ }^{5}$ Dakle, u ovom ću članku nastojati ponuditi interpretaciju romana $\mathrm{Na}$ rubu pameti kroz vizuru povijesti mentaliteta, gdje će izostati, dakako, interpretacije pojedinih likova, a što je do sada i učinjeno (npr. D. Bačić-Karković, A. Flaker, K. Nemec), kao i narativne (npr. V. Biti, M. Čale, J. Wierzbicki) ili, pak, stilske strategije (npr. N. Milošević, V. Žmegač). O političkom kontekstu romana Na rubu pameti usp. Lasić (1970) i Flaker (1999). Zadržala sam se na povijesti mentaliteta u kontekstu ulaska Hrvatske u jednu novu političku miksturu ili Krležinim određenjem: “S ljudima zajedno smrdi, ali je toplo" (Krleža 2014: 19). Dakako, moguće je navedeni roman iščitati i iz nekih drugih pozicija kao npr. i iz vizure ljubavnoga romana koju je, među ostalim, predložio Stanko Lasić, dakle, na tragu transgresije homo politicusa u homo eroticusa (transgresija od nadređene hijerarhije, heteronomije prema erotičkom krilu autonomije): Domaćinski - Doktor - Jadviga Jesenska kao autonomna odmetnica, brodolomka, anatemizirana kao raspuštenica, trostruka udovica, priležnica koja živi od prodaje vlastitoga tijela, a koja svoju prethodnicu ima, kako to nadalje demonstrira Lasić, u androginoj Bobočki (usp. Tkalčić 2015). 


\section{ANARHOINDIVIDUALIZAM I BUDDHISTIČKI ATEIZAM}

Maja Bošković-Stulli navodi da s moskovskim, Staljinovim procesima tada nije bila upoznata, kao uostalom i kružok u kojemu se kretala, ali da su, dakako, bili užasnuti paktom Hitlera i Staljina, zbog međusobne podjele Poljske i ruskoga rata u Finskoj. U kontekstu navedenoga ističe da im je bilo utoliko lakše jer su bili izvan KPJ i njezinih stega te kako su im u tim stavovima pomogli Krležin roman $\mathrm{Na}$ rubu pameti (1938.) kao i Pečat s Dijalektičkim antibarbarusom (1939.), koji naslovno evocira Erazmov tekst Antibarbari, "u kojemu se u uzajamnu ovisnost stavljaju ne samo caritas i scientia nego i humanitas i libertas" (Flaker 1988: 348). Pritom je, među prvima, Maja Bošković-Stulli negirala Lasićevu tezu da je zagrebački revizionizam, koji je predvodio Krleža, bio varijanta lenjinističkog esencijalizma (Bošković-Stulli 2007: 64). Naime, poglavlje "I mjesečina može biti pogled na svijet", u kojemu faustovski Doktor, koji dakako kao autorov alter ego (jedan od njegovih alter ega), ${ }^{6}$ u zatvoru razmišlja o ulozi pogleda na svijet (kao samoobrambenih metoda) kroz historiju koji plaze "kao zmijurine po prašumama" (Krleža 2004: 142), izravno je izazvano odjecima Staljinovih procesa 1936.-1938., što je otvorilo i Krležine otpore prema dogmatskim istinama KPH/KPJ. Pritom pogled na svijet (heteronomno prihvaćanje života) Krleža definira kazališnom metaforikom (theatrum mundi) - ljudi kao lutke na žici, a slama kojom se pune te lutke čini upravo taj velecijenjeni, cilindraški pogled na svijet stečen odgojem, dresurom, konvencijama, praznovjerjem, predrasudama, lažima, jednoumljem. Viktor Žmegač roman Na rubu pameti uzima kao model razmatranja antiteze koja tvori mentalni obrazac refleksije: s jedne, negativnokvalitativne strane - ljudi kao marionete u životnom okviru glume - theatrum mundi u kojemu postoji unaprijed provedena podjela uloga, disciplina igre prema uglavljenim pravilima te vertikalna struktura ovisnosti; hijerarhija s vrhunskom instancom metafizičkoga redatelja; ljudi na žici, ljudi nošeni pogledima na svijet i s druge, pozitivnokvalitativne strane - autonoman čovjek bez atributa društvenoga položaja (Žmegač 1986: 251-252). ${ }^{7}$

Da sažmemo, roman Na rubu pameti, kao što je dobro poznato, doživio je najžešće kritičke napade iz socrealističkog tabora (roman je iz svojevrsnih političkih razloga ponovo objavljen tek 1954.) - iz redova lijevih dogmatskih

${ }^{6}$ Ivan Goran Kovačić bilježi da najveću vrijednost romana "pruža ostvarenje piščeve imaginacije na njegovoj vlastitoj koži" (Kovačić 1963: 226). Morana Čale, pozivajući se na (Genetteove) narativne kategorije tko govori (u pripovjednom testu) i tko piše (u životu), zamjećuje, pak, sljedeće: “U svakom slučaju, autora Krleže nema u romanu, osim 'na rubu' koji je performativ pripovijedanja” (Čale 2008: 87).

${ }^{7}$ Viktor Žmegač daje iznimnu analizu Krležinih dokumenata mentaliteta prema horizontali i vertikali te utvrđuje da je Jorik u Lutkama u Banketu u Blitvi srodan Petrici Kerempuhu (Krležin alter ego) - "Njegov mentalitet nije određen vertikalom, već horizontalom" (Žmegač 1986: 202). 
kritičara, i poslužio kao povod obračunu komunističkih intelektualaca krajem tridesetih godina u sukobu na književnoj ljevici. ${ }^{8}$

Ognjen Prica posebice se kritički obrušio na poglavlje Intermezzo u Siksti$n i$, a na njegovu invektivu da Doktor, koji glas savjesti podiže protiv etičkoga i estetičkoga "dvopapkarstva", zastupa, prema Pricinu shvaćanju, "dvopapkarsku teoriju umjetnosti", Krleža mu odgovara polemički u Dijalektičkom antibarbarusu. Milovan Đilas, u kontekstu sukoba na ljevici, upozorio je da je roman Na rubu pameti jedna od kulminacijskih točaka Krležina navodno negativnog razvoja koji je započeo Povratkom Filipa Latinovicza (1932.) gdje se estetski/etički približio beogradskim nadrealistima (Marko Ristić et al.).

Đilas je tada, kako navodi Lasić, Krležu kategorizirao (starogrč. kathegorein - javno optužiti) u suprotan tabor radničkoj klasi, a pritom mu je bitno "da je sve to o tim nemogućim 'pogledima nas svijet' napisano i objavljeno poslije velikih moskovskih procesa (1936.-1938.): umjesto da pomogne radničkoj klasi u odsutnoj bitki, Krleža širi nevjericu jer njegov junak (a to znači on sâm) dolazi do zaključka da je povijest posvuda ista, da nema istine, da nema pravde, da nema progresa - čovjek je bezglava i bjesomučna životinja koja 'i tamo i ovdje ubija u ime pogleda na svijet'” (Milovan Đilas, prema Lasić 1989I: 276). Osim spomenutoga, socijalnoj je literaturi smetalo što Doktorova pobuna nije klasno motivirana, već je (anarho)individualistička.

U kontekstu povijesti mentaliteta ${ }^{9}$ možemo spomenuti da je 1936. godine svojim Baladama Petrice Kerempuha Krleža demonstrirao da ga ne zanima velika povijest, povijest velikih političkih muževa i očeva, već dimenzije povijesnosti donjega rakursa, perspektive povijesti svakodnevice poniženih i uvrijeđenih (u tome smislu značajni su posljednji stihovi Balada napisani iz

${ }^{8}$ Članak Ognjena Price “Barbarstvo Krležinog Antibarbarusa” (Zagreb: [s. n.], 1940) i članak Milovana Đilasa (pod pseudonimom: Milo Nikolić) “Od nerazumijevanja do revizionizma” (Književne sveske, 1, 1940.) pokazuju da je u komunističkim kružocima roman doživljen kao ozbiljan znak Krležina skretanja u revizionizam i udaljavanja od pozicija KPJ (Visković 2001: 154). Za razliku od “drugova”, Krleža je sve svoje obrane i kritike u jeku najžešćega sukoba na ljevici, kada su nekadašnji drugovi pljuvali po njemu na ulici (doslovno, ne radi se samo o verbalnim, rekao bi Krleža, injurijama), potpisivao vlastitom signaturom. Usprkos navedenom sukobu, Đilas će u svojim kasnijim memoarima korektivno napisati: “Na Krležu mnogi danas gledaju kao na poltrona i konformista. Takvo gledanje je prebanalno, pa i netočno. Krleža je prihvatio novi poredak kao nešto za što se i sam borio, iako je bio svjestan i njegova karaktera i njegovih manjkavosti: vrlo je rijetko, protokolarno, govorio o socijalizmu i komunizmu (...)" (Đilas 2010, http).

${ }^{9} \mathrm{Za}$ razliku od psihološke odrednice mentaliteta, na kojemu se temeljila francuska povijest mentaliteta, formirana oko časopisa Annales, što su ga 1929. pokrenuli Marc Bloch i Lucien Febvre, osobno mi se čini da je Krležino demaskiranje mentaliteta bliže Bourdieuovu razmatranju koji je u teoriju društva uveo, među ostalim, dva bitna pojma s društveno-ekonomskom matricom - habitus i polje. Habitus (tip osobe - npr. umjetnički, vojnički, znanstveni habitus) i polje (društveno polje - npr. akademsko, vojničko, religijsko polje), gdje svako polje posjeduje vlastitu doksu, označavaju da u svakodnevnici određeni habitus može funkcionirati samo u odgovarajućem tipu polja. I nadalje: osobe sličnoga habitusa imaju sličan etos, slične ukuse pa i sličan govor tijela (Bourdieu 1977: 78-84), što se može jednostavno demonstrirati na primjeru Krležina demaskiranja cilindraškoga mentaliteta, ljudi-megafona. 
kritičke perspektive psećega laveža - "s kervavemi nokti v drobu, v mozgu, v žuči,/ zalajal sam kak samec, kervavi pes vmiruči"). ${ }^{10}$

Osobno me Krleža zanima kao disident svih pogleda na svijet - heteronomne pragme i dogme, pri čemu je socijalistički mentalitet $u$ ime vlastitoga anarhoindividualizma negirao i u svojoj posljednjoj drami - riječ je o filmskom scenariju Put u raj (Forum 1-2, 1970.), napisanoga na temelju novele Cvrčak pod vodopadom (1937.) i dijaloškoga fragmenta Finale. Pokušaj pedesetvjekovne sinteze iz knjige političkih eseja Deset krvavih godina (1937.). Odnosno, kako demonstrira ta sjajna duodrama, "nebeski dramolet" - koji je napisao, u njegovu određenju, "po uzoru starih crkvenih prikazanja na eshatološku temu: uboga ljudska duša kleči pred tajnom Posljednjih Stvari" ("O glavnim licima", Put u raj), te time i glavnom akteru pridaje eshatološko ime Bernardo, što priziva aktanta Marulićeva prikazanja s eshatološkim motivima (Govorenje sv. Bernarda od duše osujene) - negaciju i socijalističkoga pogleda na svijet koji zastupa književnik Bernardo, koji kao izopćenik iz vrtloga Prvog svjetskog rata pati od PTSP-a, za razliku od njegova alter ega Orlanda, zastupnika znanstvenoga, medicinskoga, mehanicističkoga, materijalističkoga pogleda na svijet:

Orlando: Socijalizam je politika budućnosti.

Bernardo: Čovjek može biti u prezentu i bez "politike budućnosti”! (Krleža 2002: 68) ${ }^{11}$ (Navedeno je štrihano u Fanellijevu filmu Put u raj, 1970.)

Tako i 1970. godine Krleža se vraća anarhoindividualnim izvorištima - Stirneru i njegovu djelu Jedini i njegovo vlasništvo (1844.), kojemu posvećuje "knjigu" aforizama Mnogo pa ništa, pod datumom 19. svibnja 1916. Davnih dana, a koju ispisuje kao parafrazu prema Stirneru: "Ich habe meine Sache auf Nichts gestellt" (usp. Marjanić 2005: 218-248). Ili kako je to aforistički Krleža sročio u razgovoru s Matvejevićem: "Anarhoindividualni istupi su leptiri pod nogom golemih diluvijalnih životinja" (Krleža, prema Matvejević

${ }^{10}$ Upravo ta dva posljednja stiha Balada nalaze se na spomen-ploči Krležine rodne kuće - današnja Radićeva broj 7 (nekadašnja Duga ulica). (Iako je zaveden da je rođen u Petrinjskoj 4.) Često će Krleža poput Kamila Emeričkog (alter ego) vlastita kronodogađanja povezivati s anamorfozom korijena/biti povezan uz/za zemlju: "To što mene interesira to je ova moja zemlja. Ovaj krastavi pas na lancu tamo $\mathrm{u}$ blatu. Ove petrolejke u magli, to je moja domovina. Bio sam i ostao vezan uz našu bijedu, to je tako. Nisam emigrant i desilo se ma šta, nikada se neću iseliti, netko mora i ovdje ostati" (Krleža, prema Gerner 1993: 30, Zastave); ili - "Mene ne zanima politika kao karijera. Mene zanima ovaj krastavi pas na lancu tamo u blatu. Ove petrolejke u magli, jer to je moja domovina..." (Krleža, prema isto: 84, Zastave).

${ }^{11}$ Dakako, u nekim drugim vremenima Krleža je vjerovao socijalističkom pogledu na svijet. Tako $\mathrm{u}$ predgovoru Enciklopediji Leksikografskog zavoda (1955.-1964.) Krleža navodi da ona mora utjecati na izgradnju socijalističkoga mentaliteta: "Za pojačavanje lične inicijative, za uzdizanje ponosa nad postignutim, vlastitim i tuđim rezultatima, za povišenje radnog elana, za stvaranje suvremenog socijalističkog mentaliteta, za što potpunije shvaćanje smionog kretanja ljudske misli, za suvremenu i čovjeka dostojnu koncepciju društvenih pogleda (...)" (Krleža, http). Ipak, u Predgovoru drugom izdanju Enciklopedije Leksikografskog zavoda (Redakcija EJLZ) navedeni se socijalistički mentalitet više ne spominje. Znakovito. 
1982: 237). Krleža je očito bio svjestan da navedeni konstativ kroz Bernarda kao dramskoga fokalizatora (ili kako bi ga odredio Jan Wierzbicki - misaonoga subjekta) može napisati iz razloga što je tada, krajem 60 -ih, bio malo čitan, pa u tome smislu pitanje cenzure nije bilo realno. Ukratko, sjedinjujući dvije teme - temu meditacije o smrti iz novele Cvrčak pod vodopadom, ili kako Bernardo apostrofira, da "mrtvih oko nas ima više nego nas živih" te su zapravo oni "kozmička masa", a živi samo njihovi sateliti, te temu vječnog ponavljanja istoga iz Finala, Krleža tim "antiratnim rekvijemom" dramski zaokružuje vlastito viđenje globalne distopije i antiutopije - rat kao oblik legaliziranoga nasilja.

Inače, u navedenoj drami Krleža je dao sintezu pet pogleda na svijet: i dok moralisti nastoje performativno riječima djelovati na svijest i savjest gomile, naivni buntovnici opredjeljuju se za (anarho)individualne akcije, cinici pak pokazuju desperatersko gađenje nad svijetom, silnici provode nasilje i proglašavaju ga pravdom - dakako u ime vlastitoga pogleda na svijet, a konformisti mu se prilagođuju iz gluposti, sebičnosti ili, pak, (većinom) straha (Senker 1999: 246-247). Očito je da i u romanu Na rubu pameti Krleža mentalitete promatra iz matrice etosa (kontrapunkt između heteronomije i autonomije), a pritom se cjelokupno njegovo književno stvaralaštvo može interpretirati kao historija mentaliteta - dokumentarna vizura o mentalitetima svakodnevice iz po/etičke, političke, nacionalne i religijske vizure. Odnosno, Krležinim određenjem:

\begin{abstract}
Mentaliteti su ti koji razdvajaju ljude i narode, a to nam dokazuju svi građanski ratovi unutar jednog jedinstvenog jezičnog područja. Poznato je da mentaliteti nisu idealističke konstante i da se javljaju kao odraz društvenih struktura ili infrastruktura, kojima su uslovljeni. Međutim, historija nas uči i to da postoje mentaliteti koji traju po zakonu duhovne tromosti vjekovima kao davne preživjelosti, premda se infrastruktura na kojoj počivaju već davno izmijenila u svojim elementima. (Krleža 1975/1971: 752-753) ${ }^{12}$
\end{abstract}

U okviru navedenih modusa mentaliteta navodim samo jedan primjer, i to iz Davnih dana, Krležinog dnevnika iz Prvog svjetskog rata, a koji korespondira s Krležinim demaskiranjima mentaliteta u romanu o ljudskoj gluposti. Slijedi primjer za mentalitet svakodnevice. Mikrohistorijskim rastvaranjem skrivenoga "životnoga svijeta" beamterske demokratske većine, Krleža promatra njezine androcentrične aktere kroz prizmu lokalne povijesti mentaliteta s vječnoponavljajućim toposom hrvatske krčme:

[...] upravo krčmetine... Jedini historik zagrebačkih krčama, koji je kod te rabote pokazao micheletovsku fantaziju, zvao se Ante Starčević. Starčevićeve

${ }^{12}$ Riječ je o Krležinu razgovoru za Svijet (Sarajevo), 5. veljače 1971., broj 662, str. 4-5. 
stranice o krčmama [Pisma M/magjarolacah, op. S. M.], mala remek-djela [...] Nerazmjerno bolje od sveukupne literature onoga vremena. (Krleža 1977a: 28 [usp. Vaupotić 1974: 127]) $)^{13}$

\section{ANARHOINDIVIDUALIZAM I MAZOHIZAM}

Roman Na rubu pameti, roman s fiksnom unutarnjom fokalizacijom, koji retrospektivno i u formi ispovjednoga monologa prati posljedice Doktorova ekscesa na banketu kod Domaćinskog, kako bi ga prema modusu odredio Genette (1992: 99-102), jedini je Krležin roman pisan u prvom licu jednine (pritom se fokalizator, monologist [Žmegač 1986a: 218] nalazi u otpadničkoj poziciji), i pozicionira se na graničju, prijelazu između psihološkoga (1920/1922. Tri kavaljera frajle Melanije; 1923. Vražji otok; 1932. Povratak Filipa Latinovicza) i političkoga romana (Na rubu pameti, 1938.; Banket u Blitvi, 1938., 1939., 1962.; Zastave, u: Forum, 1962.-1968.) (Vučković 1986: 387). ${ }^{14}$

Upravo se iz pozicije autsajderstva pripovjednom strategijom demaskira suodnos između dogme i čovjeka-pudla, u značenju Kranjčevićeva Gospodskoga Kastora (1891.), odnosno zbog čega dogma zahtijeva pudle, ali ne mefistofelovske crne pudle, već Kastore u smislu koncepta narodnoga rasnoga homo cylindriacusa, predstavnike socijalno uslovljenoga karusela, gdje Krleža od rekvizita građanske odjeće oblikuje metonimiju čitave civilizacije (Wierzbicki 1980: 202). ${ }^{15}$ Dogma demonstrira zbog čega je ljudska glupost vječna, institucijski podržavana, dok je pobuna protiv nje (anarho)individualna i unaprijed osuđena na neuspjeh (Nemec 1998, 2000). U toj otpadničkoj poziciji Doktor, kao misaoni subjekt u opoziciji spram postvarene civilizacije lutaka (Wierzbicki 1980: 202), nema pogleda na svijet (Krleža 2014: 139): Doktor zastupa relativistički pluralizam s obzirom na to da se kroz stoljeća

${ }^{13}$ I danas se koristi Krležina vrlo moćna sintagma balkanska krčma, kao oznaka univerzalnoga mentaliteta ex-Yu: "Kad se u balkanskoj krčmi pogase svjetla, onda sijevaju noževi” (prema "Balkan”, http).

${ }^{14}$ Radovan Vučković ističe da je Krleža vjerojatno najbliži u tom romanu konceptu tadašnje socijalne proze, koja je prihvatila odlučniji eksperiment forme u prikazu aktanata zla - univerzalnoga izrabljivača u liku i djelu Domaćinskog. No za razliku od socijalne literature u ovom romanu polarizacije nisu izvedene na klasnim osnovama (što je temeljna sociemska odrednica socijalne literature), već na etičkim polarnostima u smislu dualizma dobra i zla (Vučković 1986: 388, 395), rekla bih na temelju razlike u mentalitetima, pogledima na svijet.

${ }^{15}$ Navodim neke od zoometafora kojima protagonist, u okviru Krležine negativne antropologije, određuje stanje biti homo cylindriacus (fijakerski i cilindraški građanin): preživači u štali, dvopapkari (usp. Nietzscheov pojam Herdenvolk), njuškanje pod tuđim repom; pudli - gdje figure poput Domaćinskog zahtijevaju - kako faustovskom Doktoru u ludnici pojašnjava formulu društveno poželjnoga ponašanja doktor Katančić - da se vučemo kao pudl oblizujući im ruke za tri špricera (usp. poglavlje Među brodolomcima). 
pogledi na svijet roje kao majske krijesnice, razumijevajući pritom da između vjere i znanja zapravo nema nikakve razlike (isto: 143).

Dogma se očituje kao monolitna svijest jednoumlja, odnosno kao što Doktor, koji je autonomiju pobune osjetio tek u 52. godini života, navodi - "bio sam uredna ništica među masom urednih sivih ništica [...] bio sam pravni zastupnik Domaćinskijevih poduzeća i kartela" (Krleža 2004: 11). Stanko Lasić prvi će istaknuti trijadu koja vodi anarhoindividualnoga pojedinca preko triju simboličnih "postaja" koje protagonist prolazi u svojoj kafkijanskoj Kalvariji - sudnice (dakako, s konceptom montiranoga suđenja - razgovaramo, ali prema prethodno složenim didaskalijama i monolozima), zatvora i ludnice - u totalnu osamu (Nemec 1998, 2000), istaknuvši da se sâv šarm navedenoga romana nalazi u specifičnom mazohizmu o svijesti u socijalnu pravdu: "intelekt uživa u svom porazu, jer je taj poraz svjedočanstvo o njegovoj ispravnosti i veličini" (Lasić 1974: 21). ${ }^{16}$ "Istina je: bio sam prilično sam, ali osamljenost još uvijek nije dokazom da čovjek nema pravo" (Krleža 2004: 50) - navedenim spoznajno-mazohističkim konstativom Krleža završava treće poglavlje "Vjetar nad malim gradom" romana o ljudskoj gluposti.

I dok je po političkoj niši roman Na rubu pameti blizak ideosferi anarhoindividualizma, što se tiče stila, zbog učestalosti hiperboličnih ikonograma, možemo reći da je Krleža blizak agonizmu, agonističkom mentalitetu (usp. Poggioli 1975: 100). Renato Poggioli upućuje na to kako stanje duha koje se

${ }^{16}$ Sličnu je trijadu moći dogme nedavno novinar Petar Stošić prepoznao u slučaju bivšega grčkoga ministra financija Yanisa Varoufakisa kad je dao ostavku nakon provedenoga referenduma: "prvo te ignoriraju, pa te ismijavaju (i preziru)... dalje znate i sami" (Stošić 2015, http). Naime, Varoufakis vrlo je brzo shvatio da kada Bruxelles traži prijedlog da navedeno samo i jedino znači pristanak na sve uvjete i jednoumlje heteronomne demokracije kakvu metonimijski predočuje Europska unija. Navedenu trijadu možemo svesti na dijadu koju je tematizirao Claude Lévi-Strauss u Tužnim tropima, odnosno da su se na drugost drugih uvijek primjenjivale samo dvije strategije - jedna antropoemetična, s ciljem protjerivanja drugih, i druga antropofagična, s namjerom da se drugost drugoga poništi. Koncept anarhoindividualizma možemo interpretirati i budistički, da ostanemo u duhu Krležine prakse u romanu Na rubu pameti. Jednu od zanimljivih usporedbi navodi Josip Zanki: "U školi Thangde Gatsal sam se uvjerio kako i thangka majstor kao i pomoćnici sve poslove obavljaju s jednakom pozornošću: kuhaju čaj ili tibetsku tjesteninu, pripremaju boju, kidaju drva za ogrjev, mole se u hramu i slikaju. I u svemu tome nema hijerarhije niti važnih ili nevažnih poslova. Svaka je stvar dio totaliteta i kozmičkog reda te se poštuje na jednaki način. Upravo na njihovom primjeru možemo govoriti o promjenjivom drugom kao obliku drukčijeg bivanja u svijetu. To Drugo ne podrazumijeva veliku promjenu niti svjetsku revoluciju već samo unutarnju preobrazbu kojom možemo gledati izvan bilo kakve dogme" (Zanki 2015, rkp). Potpunim čišćenjem svih dogmi moguće je suprotstaviti brisanje bitnoga i nebitnoga, o čemu svjedoči i kraj romana s hamletovskom, individualističkom i solipsističkom nirvanom. Viktor Žmegač svršetak romana, dvanaesto poglavlje "Među brodolomcima", smatra najoriginalnijom epizodom u Krležinu pripovjednom stvaralaštvu te jednim od "najosebujnijih književnih uobličenja istodobnosti u povijesti simultanizma”. U trenutku intenzivnog doživljaja vlastite osamljenosti, stanja "na rubu pameti”, Doktoru pada na pamet "bizarna ideja" da otvori radio i pobjegne u zvukove, i pritom Krleža primjenjuje akustički simultanizam koji se temelji na disparatnom nizanju kaosa, a opisu zvukova iz radija pridodane su i reakcije Doktorove svijesti na te zvukove koji registriraju svjetski metež "u tmini između plesova i pokolja”. Kao spasonosna formula iz te kakofonije, historije čovjeka kao ambivalentnoga bića - kao krvoloka i kreatora - javlja se hamletovska, individualistička i solipsistička nirvana: "Spavati da nam je. Zaspati. Mirno i konačno. Nestati” (Krleža 2004: 253; Žmegač 1986a: 218-222). 
izražava hiperbolom označuje stremljenje $\mathrm{k}$ transcendentalnom poetskom idealu, kao i pokušaj brisanja granica, intermedija (između) Čovjeka i Prirode. Kozmičke slike razotkrivaju agonističko stanje duha, ili kao što detektira Trocki: "Hiperbolična slika odražava do određene točke bijes našeg vremena" (prema isto: 204).

Ukratko, Krležin roman $\mathrm{Na}$ rubu pameti dokumentira poglede na svijet svih modusa koje je isto tako alegorijski reprezentirao George Grosz na svojoj slici Stupovi društva (1926.), naslovno referirajući na Ibsenovu dramu, a pritom je Krleža zasigurno aplicirao Domaćinskijev noćni lonac s figure novinara s noćnim loncem na glavi kako ga politički karikaturalno reprezentira Groszova slika. Dakle, riječ je o četverostrukom mentalitetu prijeratne Njemačke prema Groszovoj detekciji, o čemu je pisao i Krleža u svome eseju o Groszovu slikarstvu iz 1926. godine, iste godine kada i datira Groszova slika. ${ }^{17}$ Navedimo te stupove društva: na prvom mjestu, aristokrat koji je označen (kao uostalom i danas) svastikom (heteronomnom moći), pri čemu mu iz glave izviru konji rata; zatim, novinar s noćnim loncem na glavi; slijedi socijaldemokrat s glavom smeća/izmeta i pri samom vrhu društvene piramide svih stupova društva - svećenik, kao uostalom i danas, za vijeke vjekova. Pritom nije slučajno da veleindustrijalac Domaćinski (koji se upisuje u galeriju glembajevskih likova) čita Alfreda Ernsta Rosenberga (1893.-1946.), filozofa i ideologa nacističke stranke.

\section{BEZ AUTORITETA/MENTALITETA ILI NIRVANA S ODSUSTVOM POGLEDA NA SVIJET}

Druga, pak, istraživačica Instituta za etnologiju i folkloristiku, a riječ je političkoj antropologinji Dunji Rihtman-Auguštin, devedesetih je pronašla u Krležinim književnim i publicističkim svjetovima književni prostor bez autoriteta, odnosno kao što je naglasila - uvijek joj je kao istraživačici godio znanstveni prostor bez autoriteta. Pritom posebno su je zanijele Zastave (Forum, 1962.-1968.) i Krležini Dnevnici (Davni dani, u dva sveska - Dnevnik 1-2, koji obuhvaćaju vremenski horizont 1914-1921/22., Dnevnik 1933-42, Dnevnik 1943, Dnevnik 1958-69. i Zapisi sa Tržiča kao posljednja, šesta knjiga njegova dnevnika, objavljena posthumno) u kojima je, među ostalim, Krleža zabilježio niz stranica o povijesti mentaliteta te mikropovijest koja se obliku-

${ }^{17}$ U ono vrijeme Krleža prihvaća misao da tendencija "ne može da škodi stvaralaštvu", dakako uz uvjet da postoji specifičan umjetnički potencijal. Navedeno Krleža ističe u eseju o Georgu Groszu, kao što je, uostalom, i u Dijalektičkom antibarbarusu istaknuo revolucionarni performativ - "protiv tendenciozne fraze, ali za tendenciju u umjetnosti”. 
je i ostaje samo u individualnim sjećanjima (Rihtman-Auguštin 1997: 61), ${ }^{18}$ te razmatrajući stereotipove o Balkanu vezane uz lokalnu povijest, Dunja Rihtman-Auguštin zadržava se upravo na Krležinim djelima, odnosno kao što je navela:

Osjećam veliko štovanje prema Krležinoj antropologiji naših mentaliteta. Uz to, on je opisao društvene slojeve koje etnologija nije ni dotaknula, jer se bavila samo seljacima. Bilo bi zanimljivo kad bi neki etnolog "prohodao" po Glembajevima. To bi mogla biti studija o nastanku srednje klase u Hrvatskoj. (Rihtman-Auguštin 1997: 61)

Istina, i sâm je Krleža krajem šezdesetih doveo u pitanje realističnost Glembajevih, tvrdeći da u nas nikada nije bilo buržoazije usporedive po imetku, životnom stilu i načinu izražavanja s onom koja paradira na njegovoj pozornici, odnosno da bi hrvatska kultura bila sretna da smo imali takvu glembajevsku klasu, ali, eto, nismo (Kravar 2011, http).

Tako je Dunja Rihtman-Auguštin već 1998. godine, a i ranije, upravo na krležijanskom tragu, interpretirala Tuđmanovu retoriku hrvatskoga nacionalnoga mita i političkih rituala jer vjerovanje ne može ići bez performativne demonstracije tog istoga etnomita - onoga što Don Handelman određuje kao zrcalo prezentacije javnih događanja (Handelman 1998: 49) - ističući kako prvi hrvatski predsjednik ne može razumjeti političke i kulturne fenomene jer je zarobljenik nacionalnog mita te da je "svojim parapovijesnim promišljanjem, kompilacijama i plagijatima izgradio hrvatski nacionalni mit”. Naime, interpretirala je kreaciju hrvatskoga nacionalnoga mita iz zamisli Franje Tuđmana koji se temelji na nekoliko lažnih mitema: prije svega, riječ je o priči o drevnoj naciji, odnosno o navodno najstarijem europskom narodu; drugo - riječ je o mitemu o Hrvatskoj kao predziđu kršćanstva (dakle, iz regije je izdvojio samo Hrvatsku); treće - riječ je o geopolitičkom diskursu o hrvatskom "perecu", Hrvatima u BiH, a te 1998. godine navedeno se opredmetilo u autocesti kroz BiH kao simbolu povratka Hrvata odakle je navodno krenuo kralj Tomislav; četvrto - riječ je o Tuđmanovu etnonacionalnom mitu

${ }^{18}$ Dunja Rihtman-Auguštin navedeni je svojevrsni etnološki zaokret nazvala etnološki postpovijesni zaokret, gdje je riječ o uključivanju nekih starijih tekstova nacionalne književnosti. Smatra da je Krleža u našoj publicistici i književnosti napisao najzanimljiviju antropološku studiju Balkana, i kao metafore i kao stereotipa. I nadalje: "Usto je opisao balkanski mentalitet na obje razine, onako kako ga mi gledamo i Balkana kako ga/nas drugi vide. U biti Krležin je odnos spram Balkana ambivalentan. Osuđuje i u isto se vrijeme donekle divi balkanskom mentalitetu" (Rihtman-Auguštin 2000: 226), što je sve posljedica, možemo reći, Krležine antitetičke vrteške (da uporabimo Lasićev termin ili u određenju Ralpha Bogerta - naysayer) dok je još bio u austrougarskoj vojsci kao pitomac (Kadetska škola u Pečuhu, 1908.-1911., Vojna akademija Ludoviceum u Budimpešti, 1911.-1913.) i borio se između zanosa za starčevićanstvom i južnoslavenskom zajedničkom državom za koju je ubrzo, već 1913. godine, spoznao da će se odviti pod protektoratom Kraljevine Srbije. 
koji ujedno uključuje i narodnu kulturu, a tu je prije svega, kako zamjećuje Dunja Rihtman-Auguštin, tamburica. Odnosno, njezinim zaključkom:

Čini se da je taj hrvatski nacionalni mit postao opsesija tog starog gospodina, a, kako čujem, on je čak osobno kreirao nacionalnu i državnu simboliku. (Rihtman-Auguštin 1998: 60)

Koliko je etnomitska matrica ključna i danas dokazuje prvi radni dan predsjednice Kolinde Grabar-Kitarović koji je obilježila vlastitom fotografijom za zlatnim radnim stolom Franje Tuđmana, koji se za vrijeme predsjedanja Ive Josipovića nije koristio (Vuković 2015, http), a čime je demonstrirala kako je apsolutno svjesna uloge političkoga dekora, u ovom slučaju apliciram Goffmanovo (2000: 208-235) određenje dekora s upisima nadzora i kazne. ${ }^{19}$

\section{PRVI UČINAK REALNOG}

Završno, sukob mentaliteta i autonomije promotrit ću na dvama odabranim recentnim primjerima - jednom iz suvremene akcionističke, alterglobalističke prakse, a drugom što se tiče državnoga ceremonijala - povodom ulaska Hrvatske u Europsku uniju. ${ }^{20}$ Navedeni učinci realnog demonstriraju trajnost spomenute Krležine demonstracije mentaliteta i sigurno je da bi obje izvedbe zauzele Krležinu interpretativnu praksu s obzirom na očitovanje raznorodnih struktura mentaliteta u procesu ulaska Hrvatske u jednu novu političku miksturu, melting pot, ali s prethodno preciziranim raspodijeljenim ovlastima u toj politici kulturne razlike svedene pod slogan "Jedinstvo u različitosti" (usp. Potkonjak i Pletenac 2014: 43).

Kao jedan od niza primjera alter-EU izvedbenih demonstracija koje su upriličene prigodom ulaska Hrvatske u Europsku uniju ovom prigodom navodim građansku akciju u okviru koje je rano ujutro 1. srpnja 2013. godine grupa nezadovoljnih građanki i građana Splita postavila crni najlonski pokrivač na Peristil. Dakle, prvog dana članstva Hrvatske u Europskoj uniji skupina Splićana je, prema navodima lokalnih medija, organizirala performans na Peristilu, prekrivši ga crnim najlonom, izrazivši time neslaganje s ocjenama političara da je ulazak u Europsku uniju najbolje što se Hrvatskoj dogodilo od osamostaljenja. Gestom prekrivanja Peristila crnim najlonom poručili su kako crna boja "reprezentira dubinu bezdana i srljanje hrvatske

${ }^{19}$ Taj događaj ističem, iz niza sličnih primjera ne samo političke zbilje, već i iz svakodnevice, zbog toga što se radi o prvoj hrvatskoj predsjednici.

${ }^{20} \mathrm{O}$ drugim alter-EU izvedbenim demonstracijama koje su upriličene prigodom ulaska Hrvatske $\mathrm{u}$ Europsku uniju pisala sam u članku "Izvedba EU: izvedbene demonstracije ulaska HR u EU (ili obrnuto)" (Marjanić 2015, rkp). 
političke scene u bezglavu rasprodaju naše domovine, njene baštine i suvereniteta" (Hina 2013, http). Pritom na lecima koji su pripadnici te građanske akcije dijelili bio je istaknut termin ponerologija poljskoga psihijatra Andrzeja Łobaczewskog prema kojemu je ultimativni izvor zla posljedica dvaju ljudskih faktora - prirodnog ljudskog neznanja (ignorantnosti) i slabosti, te postojanja i djelovanja statistički male (4-8\% ukupne populacije), ali ekstremno aktivne grupe psihološki devijantnih osoba (psihopata), sklone organiziranju moći na vlasti. Ignoriranje (nepoznavanje) postojanja takvih psiholoških razlika prvi je kriterij ponerogeneze koja otvara prostor da psihopati mogu nezapaženo djelovati. ${ }^{21}$ I tako je bilo sve od Crvenoga (1968.) pa do Crnoga Peristila (2008.), kao i za vijeke vjekova... Uglavnom simboli identiteta ostali su potpuno isti od pijane novembarske noći 1918., kojoj je svjedočio Krleža, pa do danas. Izvedbe zabave i užitka kao i manifestacije modusa ulaska u Europsku uniju dio su društva spektakla, odnosno prema Debordovu određenju u društvu spektakla sve životne manifestacije se reprezentiraju kao spektakularna akumulacija prizora. U svemu tome građanin se transformira u gledaoca, potrošača vizualnih spektakla, Homo Spectatora - čovjeka promatrača (Debord 1999: 9). U tome smislu, svakako bi trebalo subverzivno iščitati makro-politike političkoga spektakla kao što predstavljaju manifestacije navedenoga tipa. I uglavnom je to ono što nam donosi suvremeni oblik ponerokracije - postajemo samo promatrači, ali ne i akteri, kako je uostalom bilo i do sada/tada.

\section{DRUGI UČINAK REALNOG}

Službena proslava ulaska Hrvatske u Europsku uniju bila je obilježena gastronomskom manifestacijom "Najveća europska gozba" (Zagreb, Trg bana Josipa Jelačića, 27. lipnja 2013.) unutar koje su građani mogli uživati u jelima specifičnim za europske zemlje, i to upravo prema maksimi "kruha i igara" (G. Ut. 2013, http) barem na jedan dan.

S druge pak strane, na središnjoj proslavi ulaska Hrvatske u Europsku uniju (Zagreb, Trg bana Josipa Jelačića, 1. srpnja 2013.) recitirana je Himna slobodi Ivana Gundulića na glazbu Jakova Gotovca. ${ }^{22}$ Zamjetno je da je navede-

${ }^{21}$ Promotrimo kako je Ministarstvo vanjskih i europskih poslova Republike Hrvatske ocijenilo političko napredovanje naše države u kolonijalnom zamašnjaku prema NATO-u i Europskoj uniji: “Hrvatska je u dvadeset i dvije godine samostalnosti postala međunarodno priznata država, članica NATO-a, a sada i punopravna, dvadeset i osma članica Europske unije i s punim pravom možemo biti ponosni na ono što smo ostvarili" (http://www.mvep.hr/hr/hrvatska-i-europska-unija/obiljezavanje/).

${ }^{22}$ Na portalu Dnevnik.hr navedeno je sljedeće (sa zaključnim trima uskličnicima kako bi se politička emfaza vodećega medija dodatno psihotično, a i neurotično pojačala): “Video da se naježite: pogledajte izvedbu koja je sinoć sve oduševila! [...] ostvaren san koji je trajao od osamostaljenja: Hrvatska postala članica Europske unije!!!” (http://dnevnik.hr/vijesti/hrvatska/na-sredisnjoj-proslavi-ulaska-u-eu- 
na numera izrazito pažljivo režirana jer tijekom izvedbe zbora neprestano se uvlačila snimka spomenika bana Josipa Jelačića. Time se realizirala svojevrsna ideologijska dijada koju je upravo Krleža vrlo žestoko kritizirao: naime, u podne/epicentru ilirskoga preporoda Hrvati su igrali kontrarevolucionarnu ulogu - pomoću bana Josipa Jelačića Bečki dvor obračunao se s mađarskim revolucionarima (mađarski nacionalni pokret, 1848/49). Nagrada Hrvatima i kazna Mađarima bila je "ista" - apsolutizam; međutim, apsolutizam s naknadom Mađarima koji su uspjeli isposlovati da Bečki dvor oduzme Jelačiću banski naslov (Krleža 1977a: 274). Vrlo često Krleža je isticao kako se Ante Starčević usprotivio da se na Harmici podigne spomenik Jelačiću koga je smatrao narodnom sramotom, mizerijom i sažaljenja dostojnom kreaturom, što nikako ne ističu one stranke koje danas polaze od Starčevićeva učenja, a samom je Gunduliću Krleža spočitavao njegovu "kontrareformacionu perspektivu" pa tako i njegovoj "himni Slobodi", pridodajući kako takvih himni u evropskim književnostima onoga doba mnogo i nema. ${ }^{23}$

Politički antropolog David I. Kertzer u knjizi Ritual, Politics and Power demonstrira zbog čega je ritual dio političkoga života, i uspjeh svih političkih grupacija, bilo tzv. lijevih, desnih ili tzv. centra, počiva u načinu na koji rabe (političke) rituale i njegove simbole. Kertzer pritom ističe da ljudi teže apsolutnoj sakralizaciji društvenoga i političkoga okoliša i da se ne osjećaju ugodno bez ritualne konstrukcije političke stvarnosti (Kertzer 1988: 81), ako vlastito društvo prepoznaju samo kao puki produkt povijesti, prilagodbe na okolinu i političke borbe. Zbog toga rado pridaju kozmologijsko značenje političkom poretku, i pritom vjeruju da je društvo dio božanske zapovijedi ili plana koji je u službi nekih viših ciljeva. ${ }^{24}$ Upravo to svojevrsno kozmologijsko značenje u sekularnom obliku, u službi ideologije moći na vlasti, bilo je vidljivo na spomenutoj političkoj ceremoniji ulaska Hrvatske u Europsku uniju.

pjevana-i-himna-slobodi-ivana-gundulica---292857.html). 0 programu usp. http://dnevnik.hr/vijesti/ hrvatska/hrvatska-u-eu-program-sredisnje-proslave-na-trgu-bana-jelacica---292790.html, a dramatičnu izvedbu Gundulić - Gotovčeve himne slobodi vidi na http://www.youtube.com/watch?v=-EVG-Mr3bHk.

${ }^{23}$ Dakako da u navedenoj negaciji Gundulićeva maglena slavenstva Krleža unosi i jednostrane fakte (usp. članak o Ivanu Gunduliću u Krležijani).

${ }^{24}$ Kertzer pritom ističe kako je u izgradnji sovjetske države Trocki bio prilično uznemiren što je Crkva još uvijek imala monopol nad svakodnevnim ritualima, i pritom je inzistirao da vladajuća garnitura prepozna ljudsku/narodnu želju za teatralnim, potrebu za vanjskom manifestacijom emocija (Kertzer 1988: 81). 

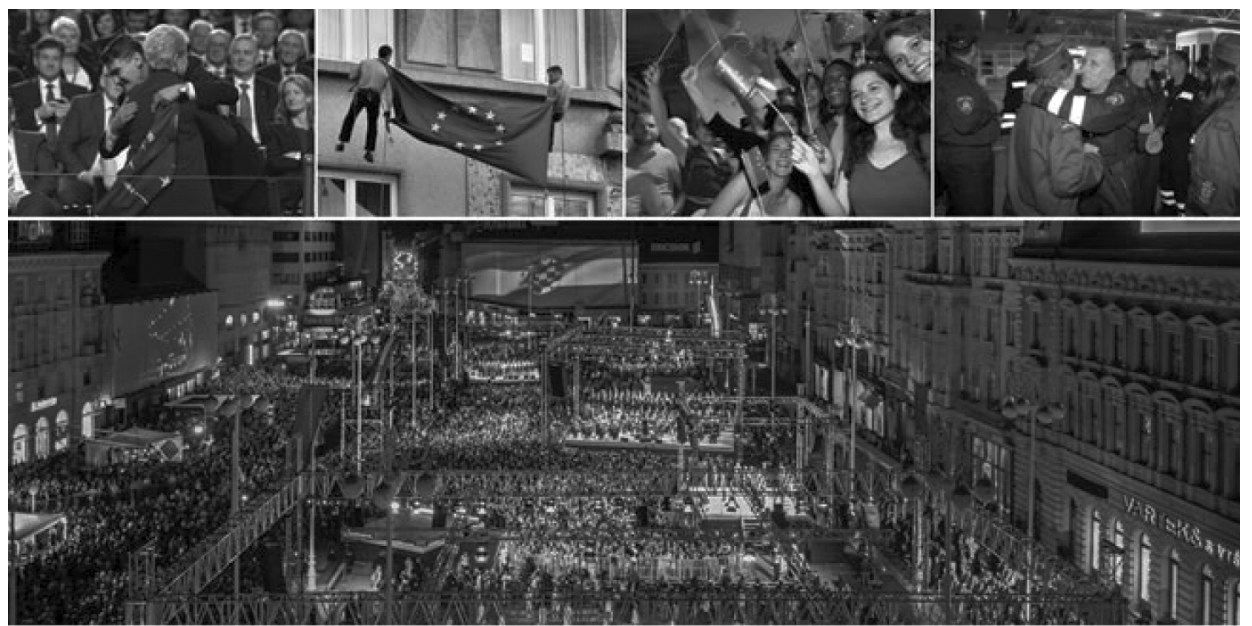

Foto 2: Politička ceremonija prigodom ulaska Hrvatske u Europsku uniju, Zagreb, Trg bana Josipa Jelačića, 1. srpnja 2013. Fotografija preuzeta s: http://www.jutarnji.hr/zagreb-danprije-unije--60-drzavnika--1100-policajaca/1111673/

\section{ANTI-ZAKLJUČNO O KRLEŽINOJ NEGATIVNOJ ANTROPOLOGIJI - ANTIČOVJEKU}

Nažalost, naši ljudi i krajevi (da uporabim Matoševu sintagmu o mentalitetnoj psihogeografiji) još su uvijek duboko zaokupljeni razlikovnim atributima $\mathrm{u}$ mentalitetima, tako da se možemo samo prisjetiti profetske opomene Charlesa Bukowskog iz njegovih dnevničkih zapisa The captain is out to lunch and the sailors have taken over the ship: "Kapitalizam je nadživio komunizam. Sada mu jedino preostaje da sam sebe proždere." Budući da filozofska antropologija (mislim i na tradicionalna filozofsko-antropološka stajališta) nastoji, među ostalim, utvrditi razlikovnu odrednicu između Čovjeka i Životinje, Krleža predočuje koncepciju filozofske negativne antropologije: njegova promišljanja o antropoteriomorfnim analogijama pripadaju antropološkoj koncepciji negativnih teorija o Čovjeku koje nalazimo od Buddhe preko Schopenhauera do Freuda. U navedeni koncept negativne antropologije ulazi i Krležino promišljanje o historiji mentaliteta jer mentalitete Krleža prepoznaje kao psihemske (usp. Peleš 1989: 254) instance arogancije i megalomanije. Čovjek stvara gledište da "moć daje pravo" prema drugima - što je Montaigne nazvao ljudskom arogancijom, a Freud - ljudskom megalomanijom (Patterson 2005: 23). Upravo su mentaliteti određeni pozicioniranjem hijerarhije, heteronomne moći - to da moć daje pravo. Spomenula bih antiutopijski (zapravo, realan, realistički) roman Istraga Phillipea Claudela koji u 28. poglavlju dokumentira provedbe strahota u najmračnijim, ali i svakodnevnim 
kafkijanskim svjetovima te ističe da se u svemu tome "[č]ovjek nije pokazao kao vuk za drugog čovjek, kako se voli reći, što je uvredljivo za vukove kao vrlo civilizirana i socijalna stvorenja, nego bi točnije bilo reći kao antičovjek, kao što fizičari govore o antimateriji" (Claudel 2014: 151-152).

Svako Krležino djelo sadrži matricu, atribuciju povijesti mentaliteta - da završno spomenem samo knjigu eseja Deset krvavih godina u kojoj je tematizirao hrvatske laži i falsifikate o vlastitome identitetu i kulturi (Luketić 2014: 195), a postavlja se u iznimno bitnu Krležinu psihobiografiju Davni dani (1914.-1921./1922.) - Deset krvavih godina. Refleksije između 1914-1924 (1924./1937.) - Zastave (1962./1968.). Ukratko, Krležina povijest mentaliteta demonstrira da je servilni mentalitet zlatne većine/sredine itekako dominanta našega političkoga i svakodnevnoga odnosa. Živjeli! Odnosno, Krležinom detekcijom: "Stepen pojedinih civilizacija stoji u obratnom smjeru sa stepenom ljudske gluposti" (Krleža 2004: 11). Zavazda...

\section{NAVEDENA LITERATURA I IZVORI}

Bačić-Karković, Danijela. 2005. Drugo čitanje. Rijeka: Izdavački centar Rijeka.

"Balkan”. Dostupno na: https://bs.wikipedia.org/wiki/Balkan (pristup 11. 5. 2015.).

Biti, Vladimir. 1984. "Krleža i evropski roman”. Književna smotra 54-55: 63-82.

Bogert, Ralph. 1991. The Writer as Naysayer. Miroslav Krleža and the Aesthetic of Interwar Central Europe. Columbus: Slavica (UCLA Slavic Studies, 20).

Bošković-Stulli, Maja. 2007. Priče iz moje davnine. Zagreb: Matica hrvatska.

Bourdieu, Pierre. 1977. Outline of a Theory of Practice. Cambridge: Cambridge University Press. [http://dx.doi.org/10.1017/CB09780511812507]

Claudel, Philipe. 2014. Istraga. Zagreb: Edicije Božičević.

Čale, Morana. 2008. "Idem prema ipse. Performativ pripovjednog identiteta". U Čale, Morana i Lada Čale Feldman. U kanonu. Zagreb: Disput, 81-94.

Debord, Guy. 1999. Društvo spektakla i komentari društvu spektakla. Zagreb: Arkzin.

Đilas, Milovan. 2010. “Memoari Milovana Đilasa, 6. Na Krležu mnogi danas gledaju kao na poltrona i konformista". Dostupno na: http://www.jutarnji.hr/milovan-dilas--na-krlezumnogi-danas-gledaju-kao-na-poltrona-i-konformista/595331/ (pristup 11. 5. 2015.).

Flaker, Aleksandar. 1988. Nomadi ljepote. Intermedijalne studije. Zagreb: GZH.

Flaker, Aleksandar. 1999. "Na rubu pameti”. U Krležijana, 2 M - Ž. Velimir Visković, gl. ur. Zagreb: Leksikografski zavod "Miroslav Krleža”, 73-76.

Genette, Gérard. 1992. "Tipovi fokalizacije i njihova postojanost”. U Suvremena teorija pripovijedanja. Vladimir Biti, ur. Zagreb: Globus, 96-115.

Gerner, Eliza. 1993. Oproštaj s Gvozdom. Razgovori s Krležom. Zagreb: AGM.

Geertz, Clifford. 1988. Tumačenje kultura, 1. Beograd: Biblioteka XX vek.

Goffman, Erving. 2000. Kako se predstavljamo u svakodnevnom životu. Beograd: Geopoetika.

G. Ut. 2013. "Na zagrebačkom Trgu 'najveća europska gozba”. Dostupno na: http://www. index.hr/black/clanak/na-zagrebackom-trgu-najveca-europska-gozba-guzve-za-besplatnu-hranu/685697.aspx (pristup 11. 5. 2015.). 
Hina; Milovan, Ariano, Tomislav Novak i Lana Bunjevac. 2013. "Hrvatska od ponoći članica EU. Spektakularna proslava u Zagrebu trajala do kasno u noć, tisuće građana dočekale ulazak u EU uz 'Odu radosti' i zvona Katedrale”. Dostupno na: http://www.jutarnji.hr/zagrebdan-prije-unije--60-drzavnika--1100-policajaca/1111673/ (pristup 10. 7. 2015.).

Hina. 2013. "Split: Crni najlon na Peristilu”. Dostupno na: http://dnevnik.hr/vijesti/hrvatska/ split-crni-najlon-uklonjen-s-peristila-prije-dolaska-policije---292905.html (pristup 10. 7. 2015.).

Handelman, Don. 1998 [1990]. Models and Mirrors. Towards an Anthropology of Public Events. New York, London: Berghahn Books.

Kertzer, David. 1988. Ritual, Politics and Power. New Haven, London: Yale University Press.

Kovačić, Ivan Goran. 1963 [1941]. “Krležino najslobodoumnije djelo”. U Miroslav Krleža. Zbornik o Miroslavu Krleži. Marijan Matković, ur. Zagreb: JAZU, 222-228.

Kozarčanin, Ivo. 1963. [1938]. "Novi Krležin roman”. U Miroslav Krleža. Zbornik o Miroslavu Krleži. Marijan Matković, ur. Zagreb: JAZU, 218-221.

Kravar, Zoran. 2011. “Glembajevski ciklus: nagađanja o recepciji”. Dostupno na: http://www. matica.hr/vijenac/456/Glembajevski\%20ciklus\%3A\%20naga\%C4\%91anja\%20o\%20 recepciji/ (pristup 11. 5. 2015.).

Krleža, Miroslav. "Enciklopedija Leksikografskog zavoda I. izdanje”. Dostupno na: http:// www.lzmk.hr/hr/izdanja/enciklopedije/311-enciklopedija-leksikografkog-zavoda-1-izdanje (pristup 11. 5. 2015.).

Krleža, Miroslav. 1977. Dnevnik 1914-17: Davni dani, 1. Sarajevo: NIŠP Oslobođenje.

Krleža, Miroslav. 1977a. Dnevnik 1918-22: Davni dani, 2. Sarajevo: NIŠP Oslobođenje.

Krleža, 2002. Put u raj: [filmski scenarij]. Zagreb: Naklada Ljevak, MH, HAZU.

Krleža, Miroslav. 1975. Panorama pogleda, pojava i pojmova. Sarajevo, Zagreb: NIŠP Oslobođenje, Mladost.

Krleža, Miroslav. 2004. Na rubu pameti. Zagreb: Biblioteka Jutarnjeg lista.

Lasić, Stanko 1970. Sukob na književnoj ljevici 1928. - 1952. Zagreb: Liber.

Lasić, Stanko. 1974. Struktura Krležinih "Zastava”. Zagreb: Liber.

Lasić, Stanko. 1989. Krležologija ili Povijest kritičke misli o Miroslavu Krleži, 1. Kritička literatura o Miroslavu Krleži od 1914. do 1941. Zagreb: Globus.

Lasić, Stanko. 1993. Krležologija ili Povijest kritičke misli o Miroslavu Krleži, 5. Književnoznanstvena metoda i literatura o Krleži: 1964-1981. Zagreb: Globus.

Luketić, Katarina. 2013. Balkan. Od geografije do fantazije. Zagreb, Mostar: Algoritam, Algoritam Stanek.

Marjanić, Suzana. 2005. Glasovi "Davnih dana". Transgresije svjetova u Krležinim zapisima 1914-1921/22. Zagreb: Naklada MD.

Marjanić, Suzana. 2015. “Izvedba EU: izvedbene demonstracije ulaska HR u EU (ili obrnuto)”. U XXV. Krležini dani u Osijeku. Zbornik radova. Branko Hećimović, ur. [u tisku].

Matvejević, Predrag. 1982. Stari i novi razgovori s Krležom. Zagreb: Spektar.

Milošević, Nikola. 1976. Andrić i Krleža kao antipodi. Beograd: Slovo ljubve.

Nemec, Krešimir. 1998. Povijest hrvatskog romana. Od 1900. do 1945. Zagreb: Znanje.

Nemec, Krešimir. 2000. Mogućnosti tumačenja. Zagreb: Hrvatska sveučilišna naklada.

Patterson, Charles. 2005 [2002]. Vječna Treblinka. Naše postupanje prema životinjama i holokaust. Zagreb: Genesis, Prijatelji životinja.

Peleš, Gajo. 1989. Priča i značenje (semantika književnog teksta). Zagreb: Naprijed. 
Poggioli, Renato. 1975. Teorija avangardne književnosti. Beograd: Nolit.

Potkonjak, Sanja i Tomislav Pletenac. 2014. “Ja, Europljanin'. Kulturna reprezentacija Hrvatske na putu u Europsku uniju". Studia ethnologica Croatica 26: 121-146.

Rihtman-Auguštin, Dunja. 1997. "Uvijek mi je godio prostor bez autoriteta”. Tjednik, 18. travnja 1997., 60-61.

Rihtman-Auguštin, Dunja. 1998. "Hrvatski intelektualci ne prihvaćaju mitove koje za svoju promociju koriste HDZ i Tuđman, iako o tome šute. Odgojeni su na Miroslavu Krleži i ne zanose se pričama o kralju Zvonimiru!". (razgovarao Mladen Pleše). Nacional, 11. ožujka 1998., 60-61.

Rihtman-Auguštin, Dunja. 2000. Ulice moga grada. Antropologija domaćeg terena. Beograd: Biblioteka XX vek.

Senker, Boris. 1999. “Put u raj”. U Krležijana, 2 M - Ž. Velimir Visković, gl. ur. Zagreb: Leksikografski zavod "Miroslav Krleža”, 244-247.

Stošić, Petar. 2015. "Kako se grčka drama približava svojem raspletu”. Dostupno na: http:// www.index.hr/vijesti/clanak/kako-se-grcka-drama-priblizava-svojem-raspletu/829912. aspx (pristup 11. 5. 2015.).

Supek, Ivan. 1992 [1980]. Krivovjernik na ljevici. Zagreb: Globus nakladni zavod.

Tkalčić, Marina. 2015. "Analiza ženskih likova u Krležinu romanu Na rubu pameti na primjeru jedanaest stereotipova Mary Ellmann". Holon: postdisciplinaran znanstveno-stručni časopis 5/1: 56-91.

Vaupotić, Miroslav. 1974. Siva boja smrti. Zagreb: Znanje.

Visković, Velimir. 2001. Krležološki fragmenti. Krleža između umjetnosti i ideologije. Zagreb: Konzor.

Vučetić, Šime. 1982. Krležino književno djelo. Zagreb: Spektar.

Vučković, Radovan. 1986. Krležina dela. Sarajevo: NIŠRO Oslobođenje.

Vuković, Rozinda. 2015. "Kolinda zasjela za Tuđmanov zlatni stol. 'Trčala sam po pustim poljima dok je vjetar šibao moje lice'”. Dostupno na: http://www.jutarnji.hr/prvi-radni-dannove-predsjednice-kolinda-vratila-tudmanov-stol-i-pocasno-postrojavanje/1298258/ (pristup 11. 5. 2015.).

Wierzbicki, Jan. 1980. Miroslav Krleža. Zagreb: Liber.

Zanki, Josip. 2015. Antropološka konceptualizacija prostora u thangka slikarstvu i suvremenim umjetničkim praksama. [Doktorska disertacija, rukopis]. Zagreb: Filozofski fakultet Sveučilišta u Zagrebu.

Žmegač, Viktor. 1986. Krležini evropski obzori. Djelo u komparativnom kontekstu. Zagreb: Znanje.

Žmegač, Viktor. 1986a. Težišta modernizma. Od Baudelairea do ekspresionizma. Zagreb: Liber. 


\title{
HOW KRLEŽA UNMASKS REALITY, OR HOW “EVEN MOONLIGHT CAN BE AN OUTLOOK ON LIFE"
}

\begin{abstract}
SUMMARY
This article deals with how Krleža unmasks mentality, or the outlook on life, through the character of the Faustian Doctor in his novel On the Edge of Reason (1938), who, as the author's alter ego (one of his alter egos) has no outlook on life of his own, because for him, ironically, "even moonlight can be an outlook on life". This negates the attribution of mentality (an outlook on life which "slithers like serpents through the jungle"), which is in opposition to an autonomous way of representing and experiencing life. Or, to use Krleža's own words from 1971: "It is mentalities that divide people and nations, as seen from all the civil wars waged within a single united linguistic area". In the second part of the article, I analyze the opposition between mentality and autonomy on two recent examples - one from the actionist / alter-globalist practice, and the other being the state ceremony on the occasion of Croatia's accession to the European Union.
\end{abstract}

Keywords: Miroslav Krleža, On the Edge of Reason (1938), mentality, Croatia's accession to the EU 